\title{
PELAKSANAAN LAYANAN BIMBINGAN KELOMPOK MELALUI PENDEKATAN TEKNIK BERMAIN PERAN DALAM MENINGKATKAN KOMUNIKASI NAPOSO NAULI BULUNG
}

\author{
Anas Munandar Matondang ${ }^{1}$ Nora Sartika ${ }^{2}$ \\ ${ }^{1}$ Program Studi Bimbingan dan Konseling Universitas Muhammadiyah Tapanuli Selatan \\ ${ }^{2}$ Program Studi Bimbingan dan Konseling Universitas Muhammadiyah Tapanuli Selatan \\ E-mail: anasmunandarbk@gmail.com
}

\begin{abstract}
Abstrak
Adapun latar belakang penelitian ini adalah berdasarkan fenomena yang terjadi di lapangan yaitu komunikasi di kalangan naposo nauli bulung kurang berkembang ditunjukkan dengan adanya gejalagejala seperti anggota naposo nauli bulung sulit untuk berpartisipasi dalam suatu acara di desa, kurangnya minat bermusyawarah antar naposo nauli bulung, sulitnya mengkomunikasikan untuk membuat acara penting di desa dikarenakan kurang aktifnya anggota naposo nauli bulung, komunikasi remaja kurang aktif dan cendrung tertutup, kurang percaya diri dalam menyampaikan pendapat, kurangnya keterampilan dalam berkomunikasi sehingga adanya kesulitan dalam menyelenggarakan kegiatan di desa. Metodologi penelitian menggunakan penelitian tindakan (action research) yang dianggap lebih detail dalam melaporkan layanan bimbingan kelompok. Subjek penelitian ini adalah naposo nauli bulung desa Sihepeng Induk yang berjumlah 30 orang. Teknik pengumpulan data yang digunakan adalah angket dan pedoman observasi. Analisis data yang digunakan adalah analisis deskriptif kuantitatif. Data penelitian ini dianalisis menggunakan rumus rata-rata dengan teknik tabulasi data secara kuantitatif berdasarkan hasil tindakan. Hasil penelitian menunjukkan naposo nauli bulung sudah cukup aktif dalam kegiatan kelompok dan berani dalam mengungkapkan pendapatnya di muka umum, walaupun tidak semua anggota kelompok, juga masih ada yang berdasarkan perintah dari peneliti baru berani, tapi secara keseluruhan sudah terlihat peningkatannya.
\end{abstract}

Kata Kunci : layanan bimbingan kelompok, bermain peran, komunikasi 


\begin{abstract}
The background of this research is based on the phenomena that occur in the field, namely communication in the Bulung Nauli Naposo circles is less developed indicated by the symptoms such as the members of the Naposo Nauli Bulung difficult to participate in an event in the village, lack of interest in deliberating between Naposo Nauli Bulung, difficulty communicating to make important events in the village due to lack of active members of the Naposo Nauli Bulung, communication of young people less active and closed, lack of confidence in expressing opinions, lack of communication skills so that there are difficulties in organizing activities in the village. The research methodology uses action research which is considered more detailed in reporting group guidance services. The subject of this study was Naposo Nauli Bulung, Sihepeng Induk village, totaling 30 people. Data collection techniques used were questionnaires and observation guidelines. Data analysis used is quantitative descriptive analysis. This research data was analyzed using an average formula with quantitative data tabulation techniques based on the results of the action. The results of the study showed that Naposo Nauli Bulung was quite active in group activities and dared to express his opinion in public, although not all members of the group, there were also those who were based on orders from new researchers who were brave, but overall the improvement was seen.
\end{abstract}

Keywords: Group guidance, role playing, comunication

\title{
PENDAHULUAN
}

Manusia sebagai mahluk sosial tidak dapat melepaskan diri dari jalinan relasi sosial, dimana manusia selalu akan mengadakan kontak sosial dan selalu berhubungan dengan orang lain, seperti yang diketahui bahwa komunikasi merupakan faktor penting dalam kehidupan, karena tanpa adanya komunikasi kegiatan manusia tidak akan berjalan dengan baik. Melalui komunikasi diharapkan dapat membawa hasil pertukaran informasi dan saling pengertian diantara orang yang terlibat dalam kegiatan tersebut.

Kita sadar bahwa banyak hal yang terjadi dilingkungan sekitar. Semakin berjalannya waktu semakin banyak fenomena-fenomena yang terjadi dan seiring waktu dengan segala kesibukan manusia yang terkadang lupa untuk menyisihkan waktunya untuk masyarakat apalagi dengan teknologi yang berkembang manusia kadang mempunyai cara pandang yang berbeda, yang berpikir bahwa dengan teknologi itu semua kegiatan hidup dapat berjalan dengan lancar dan kadang melupakan budaya yang sudah melekat dalam masyarakat.

Manusia sangat percaya bahwa segala sesuatu yang dilakukan secara bekerjasama itu akan mudah dilaksanakan tapi terkadang kita gagal dalam merencanakan, mengkomunikasikan, dan terhambat dalam pelaksanaan. Naposo nauli bulung kadang melupakan peran dan tanggung jawabnya terhadap masyarakat yang seharusnya membantu masyarakat dalam melaksanakan adat dan juga membantu dalam melaksanakan kegiatan keagamaan, tetapi yang terjadi malah sebaliknya dan yang bermasalah disini adalah kurangnya kemampuan naposo nauli bulung dalam menjalin komunikasi yang baik sehingga kegiatan yang dilaksanakan di desa kurang 
terlaksana dengan baik padahal banyak sekali harapan para orang tua, hatobangon, harajaon dan juga masyarakat lain akan berkembangnya desa ini.

Terhambatnya komunikasi dialami oleh banyak orang dalam berbagai profesi. Bahkan tidak sedikit orang yang kurang menghargai pentingnya peranan komunikasi dalam kehidupannya, sebaliknya orang-orang yang pandai memanfaatkan komunikasi kehidupannya cenderung berkembang pesat, baik dalam berusaha maupun dalam berorganisasi sosial. Pentingnya komunikasi bagi manusia tidaklah dapat dipungkiri begitu juga halnya bagi suatu organisasi. Dengan adanya komunikasi yang baik suatu organisasi dapat berjalan lancar dan berhasil dan begitu pula sebaliknya. Kurangnya atau tidak adanya komunikasi yang baik suatu organisasi dapat berantakan.

Menurut Carl I. Hovland (Riswandi, 2013:1) komunikasi adalah suatu proses yang memungkinkan seseorang menyampaikan rangsangan (biasanya dengan menggunakan lambang verbal) untuk mengubah perilaku orang lain.

William J. Seller (Riswandi, 2013:2) mengatakan bahwa komunikasi adalah proses dimana simbol verbal dan nonverbal dikirimkan, diterima dan diberikan kesimpulan: Komunikasi adalah pesan yang disampaikan kepada komunikan (penerima) dari komunikator (sumber) melalui saluran-saluran tertentu baik secara langsung/tidak langsung dengan maksud memberikan dampak/effect kepada komunikan sesuai dengan yang diinginkan komunikator.

Penelitian yang relevan dengan penelitian yang peneliti lakukan adalah penelitian Muhammad Ridwan Arif (2014:4) dengan judul "Peran Karang Taruna Dalam Pembinaan Remaja di Desa Candi Negoro Kabupaten Sidoarjo". Yang menyimpulkan bahwa:

"Peran karang taruna dalam pembinaan perilaku remaja di desa sangat tinggi tetapi masih perlu peningkatan dalam pengetahuan untuk membina remaja agar sesuai dengan harapan, sehingga perlu kerja sama yang baik antara pengurus desa agar mampu menciptakan remaja yang berkualitas dan dapat diandalkan dilingkungan masyarakat. Setelah penelitian para generasi muda mampu bekerja sama dan bertanggung jawab sosial untuk masyarakat".

Sehubungan dengan penelitian ini, layanan bimbingan konseling sangat besar usaha pemantapan arah hidup generasi muda dalam berbagai bidang ilmu pengetahuan, keterampilan, dan sikap mental dalam masyarakat. Bimbingan kelompok melalui pendekatan teknik bermain peran akan membantu naposo nauli bulung untuk meningkatkan komunikasi di desa.

Teknik bermain peran atau sosiodrama menurut Roestiyah (2012:90) ialah siswa/klien dapat mendramatisikan tingkah laku, atau ungkapan gerak gerik wajah seseorang dalam 
hubungan sosial antar manusia. Atau dengan roll-playing dimana siswa/klien bisa berperan atau memainkan peranan dalam dramatisasi masalah sosial/psikologis itu.

Fenomena yang terjadi di masyarakat desa penelitian terdapat peristiwa yang sulit dilaksanakan oleh semua pengurus desa ketika akan dilaksanakan suatu kegiatan keagamaan atau yang bersangkutan dengan musyawarah untuk pelaksanaan kegiatan untuk keharmonisan masyarakat desa Sihepeng Induk. Komunikasi di kalangan naposo nauli bulung kurang berkembang ditunjukkan dengan adanya gejala-gejala seperti anggota naposo nauli bulung sulit untuk berpartisipasi dalam suatu acara di desa, kurangnya minat bermusyawarah antar naposo nauli bulung, sulitnya mengkomunikasikan untuk membuat acara penting di desa dikarenakan kurang aktifnya anggota naposo nauli bulung, komunikasi remaja kurang aktif dan cendrung tertutup, kurang percaya diri dalam menyampaikan pendapat, kurangnya keterampilan dalam berkomunikasi sehingga adanya kesulitan dalam menyelenggarakan kegiatan di desa. Dari fenomena yang terjadi dapat dikatakan bahwa naposo nauli bulung Sihepeng Induk komunikasinya kurang berkembang secara optimal.

Permasalahan tentang kurangnya komunikasi dikalangan naposo nauli bulung mungkin saja terjadi karena masih kurangnya kesadaran di naposo nauli bulung desa tentang kebersamaan, kekompakan, dan makna sosial dan masing-masing kurang berminat dalam bermusyawarah untuk kemajuan desa. Berdasarkan wawancara pada tanggal 2 November 2017 menurut Ilman Habibi naposo nauli bulung adalah sebuah organisasi kepemudaan yang berada di sebuah desa atau kampung dan lingkungan masyarakat, yang menjadi anggota naposo nauli bulung di mulai dari kelas tiga SMP (umur 14 tahun keatas/belum menikah). Naposo nauli bulung mempunyai fungsi untuk membantu masyarakat dalam acara-acara resmi yang diadakan di desa tersebut, menjaga keamanan kampung dan mengayomi masyarakat yang hakikatnya adalah tugas dan tanggung jawab dari naposo nauli bulung.

\section{METODOLOGI}

Peneliti menggunakan penelitian tindakan (action research) yang dianggap lebih detail dalam melaporkan layanan. Adapun layanan yang digunakan pada penelitian ini adalah layanan bimbingan kelompok yang digunakan untuk meningkatkan komunikasi naposo nauli bulung.

Penelitian tindakan terdiri dari empat jenis, yaitu penelitian tindakan diagnostik, partisipan, empiris, dan eksperimental. Dalam penelitian ini digunakan penelitian tindakan partisipan, yaitu apabila orang yang akan melakukan penelitian harus terlibat langsung didalam proses penelitian sejak awal sampai dengan hasil penelitian berupa laporan. (Paizaluddin \& Ermalinda, 2014:28) 
Selanjutnya peneliti akan memberi gambaran dengan secara cermat tentang fenomena yang terjadi bagaimana naposo nauli bulung dalam meningkatkan komunikasi. Penelitian tindakan menurut Suharsimi ( 2005:17) ialah penelitian yang berorientasi pada penerapan tindakan dengan tujuan peningkatan mutu atau pemecahan masalah pada sekelompok subyek yang diteliti dan mengamati tingkat keberhasilan atau akibat tindakannya, untuk kemudian diberikan tindakan lanjutan yang bersifat penyempurnaan tindakan atau penyesuaian dengan kondisi dan situasi sehingga diperoleh hasil yang lebih baik.

\section{a. Subjek Penelitian}

Subjek penelitian ini adalah naposo nauli bulung desa Sihepeng Induk yang berjumlah 30 orang yang komunikasinya kurang aktif dan cenderung tertutup, sedang dipilih berdasarkan hasil pre-test angket komunikasi. Berikut ini adalah daftar subjek penelitian:

Tabel 1. Subjek Penelitian

\begin{tabular}{|c|l|l|}
\hline No. & Nama & $\begin{array}{l}\text { Jenis } \\
\text { kelamin }\end{array}$ \\
\hline 1 & HIL & Laki-laki \\
\hline 2 & ABDUL & Laki-laki \\
\hline 3 & AZMI & Laki-laki \\
\hline 4 & NIK & Perempuan \\
\hline 5 & DEA & Perempuan \\
\hline 6 & BGS & Perempuan \\
\hline 7 & RAZ & Perempuan \\
\hline 8 & NKU & Perempuan \\
\hline
\end{tabular}

\section{b. Prosedur Penelitian}

Sesuai dengan jenis penelitian ini yaitu penelitian tindakan (action research), dalam hal ini, peneliti menggunakan model penelitian tindakan yang dikembangkan oleh Kurt Lewin. Masing-masing siklus kegiatan terdiri dari empat sub kegiatan yaitu, perencanaan (plan), pelaksanaan (action), observasi (observation), dan refleksi (reflection). (Paizaluddin \& Ermalinda 2014:29-30) 


\section{c. Tehknik Pengumpulan Data}

Teknik pengumpulan data yang digunakan dalam penelitian ini adalah angket dan pedoman observasi. Angket yaitu cara pengumpulan data berbentuk pengajuan pertanyaan tertulis melalui sebuah daftar pertanyaan yang sudah dipersiapkan sebelumnya. Dan untuk mengukur minat, sikap, pendapat, dan persepsi seseorang untuk kelompok tentang suatu gejala fenomena pendidikan (Djaali dan Muljono, 2017:28).

\section{d. Teknik Analisis Data}

Teknik analisis data yang digunakan dalam penelitian ini adalah analisis deskriptif kuantitatif. Data penelitian ini dianalisis menggunakan rumus rata-rata dengan teknik tabulasi data secara kuantitatif berdasarkan hasil tindakan. Hasil tindakan dideskripsikan dalam data konkrit, berdasarkan skor maksimal sehingga diperoleh nilai rata-rata.

Menunjuk pada penjelasan Saifuddin Azwar (2012:149) penentuan kategori skor komunikasi kedalam tiga kategori yaitu:
1. $(\mu+1,0 \sigma) \leq X$ $=$ Tinggi
2. $(\mu+1,0 \sigma) \leq X<(\mu+1,0 \sigma)$
$=$ Sedang
3. $X<(\mu+1,0 \sigma)$
$=$ Rendah

\section{Keterangan:}

\section{$\mu \quad$ : Mean ideal}

$\sigma \quad$ : Standar deviasi

$X \quad$ : Skor yang diperoleh

Berdasarkan hasil perhitungan diatas, didapatkan kategori sebagai berikut:

Tabel 2. Kategori Kriteria Keberhasilan

\begin{tabular}{|c|l|l|}
\hline No. & $\begin{array}{c}\text { Rentang } \\
\text { Skor }\end{array}$ & Kategori \\
\hline 1 & $84 \geq X$ & Tinggi \\
\hline 2 & $\begin{array}{l}56 \leq X< \\
84\end{array}$ & Sedang \\
\hline 3 & $X<56$ & Rendah \\
\hline
\end{tabular}


Dari tabel diatas dapat dilihat bahwa naposo nauli bulung memiliki komunikasi rendah apabila skor angket komunikasinya kurang dari 56 poin. Naposo nauli bulung dengan kategori komunikasi sedang apabila skor angket diantara 56 sampai 84 poin. Sedangkan naposo nauli bulung dengan kategori tinggi apabila skor angket komunikasi lebih dari atau sama dengan 84 poin.

\subsection{Kriteria Keberhasilan}

Kriteria keberhasilan dalam penelitian ini adalah:

1. Penelitian ini dikatakan berhasil apabila naposo nauli bulung dapat meningkatkan komunikasinya melalui layanan bimbingan kelompok dengan teknik bermain peran.

2. Apabila skor komunikasi naposo nauli bulung telah mencapai rentang tinggi atau sedang 84/56 poin, namun jika belum terjadi peningkatan, maka akan dilakukan tindakan siklus berikutnya.

\section{HASIL PENELITIAN}

\section{Deskripsi Pelaksanaan dan Hasil Tindakan}

Dalam hasil pre-test dapat dilihat naposo nauli bulung yang memiliki tingkat komunikasi rendah diambil 8 orang.

\section{a. Pelaksanaan Tindakan Siklus I}

a) Perencanaan

Tahap persiapan sudah dipersiapkan peneliti pada hari-hari sebelum melakukan tindakan. Peneliti menyajikan topik yang akan didiskusikan oleh kelompok diskusi. Dalam tindakan pertama, peneliti memberikan sebuah topik keterbukaan dalam menyampaikan pendapat yang mengarah pada perubahan sikap/perilaku seseorang, langkah-langkah untuk menyelesaikan masalah dalam topik, dan hikmah apa yang dapat diambil dari kasus tersebut.

Sebelum melaksanakan tindakan peneliti berdiskusi dengan kolaborator mengenai materi yang akan diberikan. Selain berdiskusi dengan kolaborator, peneliti juga berdiskusi dengan observer dalam mengamati naposo nauli bulung dan semua peristiwa selama tindakan.

b) Tindakan dan Observasi

Tindakan dan observasi pertama dilakukan pada tanggal 5 Maret 2018 pada pukul 04.0005.45 WIB. Pelaksanaan tindakan dilakukan diruang kantor kepala desa. Tindakan yang diberikan oleh peneliti adalah pembahasan materi komunikasi. Tindakan dan observasi kedua dilaksanakan pada hari jumat tanggal 7 Maret 2018 pukul 07.00-07.45 WIB. Tempat pelaksanaan tindakan kedua dilaksanakan diruang kantor kepala desa. Tindakan yang diberikan 
oleh peneliti adalah pemberian materi prinsip-prinsip berkomunikasi. Berikut merupakan rincian kegiatannya:

1) Pelaksanaan tindakan 1

a. Kegiatan pembuka

Peneliti, kolaborator serta observer masuk ke dalam kantor kepala desa untuk memulai kegiatan. Selanjutnya, peneliti bertanya kepada anggota kelompok "bagaimana kabar hari ini?". setelah semua anggota kelompok siap, maka peneliti menjelaskan kepada anggota kelompok mengenai maksud dari kegiatan yang akan dilakukan.

b. Kegiatan inti

Peneliti memulai kegiatan dengan bertanya kepada anggota kelompok "apakah pernah atau sedang mempunyai masalah komunikasi dengan temannya?". Setelah itu peneliti memberikan topik tugas berupa materi kegiatan bimbingan kelompok dengan teknik bermain peran yaitu prinsip-prinsip berkomunikasi untuk didiskusikan masing-masing anggota kelompok. Saat waktu yang sudah ditentukan berakhir, peneliti mengajak seluruh anggota kelompok untuk mendiskusikan secara bersama-sama. Hasil diskusi kelompok kemudian dibacakan salah satu anggota kelompok.

c. Penutup

Kegiatan penutup dilakukan dengan memberikan pertanyaan secara acak pada anggota kelompok untuk mengetahui seberapa besar pemahaman naposo nauli bulung mengenai materi yang telah dibahas. Peneliti menutup kegiatan pada siklus I pertemuan 1 dengan memberikan kesimpulan dan evaluasi terhadap kegiatan yang dilakukan, serta sekilas tentang kegiatan yang akan dilakukan pada pertemuan berikutnya.

2) Pelaksanaan tindakan 2

a. Kegiatan pembuka

Sebelum memulai penelitian, peneliti, kolaborator, dan observer melakukan diskusi terlebih dahulu dengan tujuan kegiatan diskusi akan lebih baik dari yang sebelumnya. Setelah itu peneliti bersama observer masuk ke ruang kantor kepala desa dan membuka kegiatan. Seperti biasa peneliti memulai kegiatan dengan mengucapkan salam serta menanyakan kabar anggota bimbingan kelompok hari ini. Sebelum melanjutkan kegiatan berikutnya peneliti merefleksikan kembali hasil kegiatan yang dilakukan pada pertemuan sebelumnya.

b. Kegiatan inti

Seperti kegiatan sebelumnya, peneliti menyampaikan maksud dan tujuan, setelah selesai peneliti memberikan topik tugas yang kedua dengan materi yaitu: bebas mengeluarkan 
pendapat dan saling terbuka. Materi tersebut di bahas oleh masing-masing kelompok dan kemudian mempersentasikan hasilnya, seluruh peserta menyimak apa yang telah dipaparkan temannya.

Dalam diskusi kelompok sudah ada perbaikan dari kontribusi antar anggota kelompok, naposo nauli bulung sudah agak mau menyampaikan pendapatnya dalam menyelesaikan permasalahan yang disajikan peneliti, walaupun masih belum sepenuhnya naposo nauli bulung berpartisipasi. Selain itu diskusi kelompok juga lebih estimasi waktunya. Secara keseluruhan jalannya diskusi kelompok tidak jauh berbeda dengan pertemuan pertama, anggota kelompok masih sedikit malu memaparkan hasil diskusi kelompoknya didepan temannya.

Tetapi dipertemuan kedua ini sudah mengalami perbaikan dalam penunjukan, diantaranya peneliti tidak lagi menunjuk anggota kelompok satu persatu untuk menyampaikan pendapat dari hasil diskusinya, melainkan anggota kelompok secara suka rela bergantian mempersentasikan pendapatnya.

c. Kegiatan penutup

Dalam kegiatan penutup, peneliti memberikan kesimpulan dan evaluasi terhadap jalannya kegiatan yang dilakukan. Peneliti menutup kegiatan dengan mengucapkan salam dan terimakasih.

\section{3) Pemberian Post-test I}

Pemberian post-test diberikan untuk mengetahui ada tidaknya peningkatan yang terjadi setelah dilaksanakan tindakan 1 dan tindakan 2 pada siklus. dengan adanya post-test, dapat membantu memperkuat data hasil observasi selama tindakan berlangsung. Hasil dari post-test ini dapat digunakan untuk mempertimbangkan siklus selanjutnya perlu dilaksanakan atau tidak. Untuk mengetahui ada tidaknya peningkatan tingkat komunikasi naposo nauli bulung setelah tindakan I dan tindakan II pada siklus, dapat dilihat dengan membandingkan hasil skor skala pre-test dengan hasil post-test.

Apabila anggota kelompok telah berada dalam ketegori sedang atau tinggi maka dapat dikatakan telah berhasil meningkatkan komunikasinya. Pengukuran siklus dilaksanakan pada hari Jum'at 7 Maret 2018. Hasil Post-test I disajikan dalam tabel berikut: 
Tabel 3. Hasil Post-test I

\begin{tabular}{|c|l|l|l|}
\hline No & Kriteria & Rentang & Frekuensi \\
\hline 1 & Tinggi & $84 \geq X$ & 5 \\
\hline 2 & Sedang & $\begin{array}{l}56 \leq X< \\
84\end{array}$ & 3 \\
\hline 3 & Rendah & $X<56$ & \\
\hline
\end{tabular}

Tabel tersebut menunjukkan dari 8 anggota kelompok terdapat 5 orang yang memperoleh poin tinggi 84 keatas, memiliki kriteria poin sedang 3 orang 56 keatas. Naposo nauli bulung memiliki kriteria rendah (0) dengan poin dibawah 56. Hasil ini meningkat dari hasil pre-test yang semula menunjukkan terdapat 8 orang naposo nauli bulung memiliki kriteria rendah.

4) Observasi

Pada siklus tersebut, observasi dilakukan selama tindakan berlangsung yaitu pada tindakan I dan tindakan II. Hasil observasi pada tindakan 1, yaitu terdapat naposo nauli bulung yang masih malu-malu mengeluarkan pendapatnya karena kurang percaya diri. Hal tersebut cukup menyulitkan peneliti dalam menguasai ruangan namun hal tersebut dapat diatasi oleh peneliti dengan sedikit memberikan motivasi kepada naposo nauli bulung.

Hasil observasi pada tindakan II, sedikit berbeda dengan tindakan I dalam tindakan II naposo nauli bulung sudah mulai berani berbicara dan mengeluarkan pendapat dengan percaya diri, namun masih ada satu dua orang naposo nauli bulung yang masih malu-malu dalam menyampaikan pendapatnya. Dengan keadaan tersebut peneliti kembali memberikan dukungan dan menayangkan video motivasi kepada naposo nauli bulung agar mereka lebih semangat lagi.

5) Kesimpulan

Proses pelaksanaan penerapan bimbingan kelompok dengan teknik bermain peran untuk meningkatkan komunikasi naposo nauli bulung pada siklus I berjalan dengan lancar. Berdasarkan angket komunikasi seluruh anggota kelompok mengalami peningkatan.

6) Refleksi I

Refleksi dilakukan dengan cara bermusyawarah antara peneliti dengan naposo nauli bulung, peneliti dengan tim kolaborator. 
a) Peningkatan poin komunikasi pada post-test menunjukkan bahwa bimbingan kelompok dengan teknik bermain peran yang dilakukan peneliti mulai berhasil. Pada pre-test diketahui siswa yang memiliki komunikasi dengan kriteria rendah sebanyak 8, sedangkan pada post-test siklus I naposo nauli bulung yang memiliki komunikasi dengan kriteria tinggi 5 orang, rendah 3 orang dan rendah (0). Penelitian berhasil apabila seluruh naposo nauli bulung (anggota kelompok) memiliki komunikasi dalam kriteria sedang atau 56 poin ke atas.

b) Kedua tindakan yang dilakukan pada siklus I ditemukan sebagian naposo nauli bulung masih rendah keaktifannya dalam kegiatan diskusi. Upaya untuk meminimalkan hal tersebut, peneliti berencana melakukan perbaikan dengan memilih materi yang lebih menarik.

2. Pelaksanaan Tindakan Siklus II

a. Tahap persiapan

Seperti dalam siklus I, peneliti mempersiapkan materi yang akan diberikan pada siklus II tindakan I. materi yang akan diberikan pada siklus II tindakan I ini adalah lanjutan dari siklus I. Sebelum melakukan tindakan I di siklus II, peneliti berdiskusi dengan observer dan kolaborator mengenai materi yang akan diberikan dan memberikan lembar observasi untuk mempermudah pengamatan selama kegiatan berlangsung.

b. Tindakan dan Observasi

Tindakan I dan observasi ketiga dilaksanakan pada tanggal 10 Maret 2018 pukul 09.3010.15 WIB. Tempat pelaksanaan dikantor kepala desa Sihepeng Induk. Tindakan II dan observasi keempat dilaksanakan pada hari sabtu tanggal 14 Maret 2018 pukul 10.15-11.00 WIB. Tempat kantor kepala desa Sihepeng Induk.

1) Pelaksanaan Tindakan III

a) Kegiatan Pembuka

Peneliti bersama observer memasuki ruang kantor kepala desa dan mengucapkan salam serta disisipkan kata-kata pembangkit semangat para anggota kelompok. Tidak lupa peneliti menanyakan kabar. Setelah itu peneliti menjelaskan kembali pada anggota kelompok maksud dan tujuannya kembali lagi berkumpul dengan naposo nauli bulung yang delapan orang.

b) Kegiatan Inti

Peneliti membagikan naskah yang berisi cerita kasus kesalahpahaman dalam berkomunikasi, masing-masing anggota kelompok diminta untuk mencermati isi kasus serta menjawab beberapa pertanyaan yang ada dalam naskah. Beberapa saat kemudian masing-masing kelompok diajak untuk mendiskusikan dalam menjawab pertanyaan dalam naskah. 
c) Kegiatan Penutup

Untuk menutup kegiatan siklus II tindakan I ini peneliti membacakan kesimpulan dari diskusi dan merencanakan tindakan kedua.

2) Pelaksanaan Tindakan II

a) Kegiatan Pembuka

Peneliti memulai tindakan kedua di siklus II dengan menanyakan jadwal yang telah direncanakan sebelumnya, setelah itu peneliti kembali menyisipkan kata-kata motivasi untuk membangkitkan semangat anggota kelompok dalam pertemuan.

b) Kegiatan Inti

Peneliti memulai tindakan dengan menanyakan perubahan apa saja setelah dilakukan tindakan I, dan II. Peneliti memberikan kesempatan kepada anggota kelompok untuk menentukan sendiri materi apa yang akan dibahas pada kesempatan ini. Kemudian meminta setiap anggota kelompok menyampaikan pendapatnya dan kemudian memilih salah satu materi yang sudah mereka kemukakan tersebut untuk dibahas secara mendalam dan tuntas. Materi yang dibahas pada pertemuan kali ini adalah keterampilan dalam berkomunikasi.

Ketika waktu yang ditentukan berakhir, peneliti mengajak kembali masing-masing anggota kelompok untuk mendiskusikan hasil kerja kelompok. Setelah diskusi selesai, peneliti membagikan angket pasca siklus II kepada anggota kelompok. Anggota kelompok terlihat tidak kesulitan dalam mengisi angket komunikasi tersebut karena sudah tidak asing dengan pernyataan yang ada.

c) Penutup

Sebagai penutup peneliti memberikan kesan-kesan selama melaksanakan kegiatan penelitian di desa Sihepeng Induk. Tidak lupa peneliti meminta maaf dan atas segala kesalahan yang dilakukan dan berterima kasih atas bantuan seluruh naposo nauli bulung desa Sihepeng Induk.

3) Pemberian Post-test II

Post-test II diberikan untuk mengetahui ada tidaknya peningkatan yang terjadi setelah dilaksanakan tindakan I dan tindakan II pada siklus II. Dengan adanya Post-test II dapat membantu memperkuat data hasil observasi selama tindakan berlangsung. Untuk mengetahui ada atau tidaknya peningkatan setelah tindakan siklus II dapat dilihat dengan membandingkan hasil poin angket komunikasi Post-test I dengan hasil poin angket komunikasi Post-test II. Pengukuran Post-test II dilaksanakan pada hari sabtu tanggal 20 Maret 2018. Hasil dari siklus ini dapat dicermati pada tabel di bawah ini: 
Tabel 11. Hasil Post-test II

\begin{tabular}{|c|l|l|l|}
\hline No & Kriteria & Rentang & Frekuensi \\
\hline 1 & Tinggi & $84 \geq X$ & 8 \\
\hline 2 & Sedang & $\begin{array}{l}56 \leq X< \\
84\end{array}$ & - \\
\hline 3 & Rendah & $X<56$ & - \\
\hline
\end{tabular}

Dari tabel di atas, dapat diketahui bahwa siklus II tersebut menunjukkan bahwa semua anggota bimbingan kelompok yang berjumlah 8 orang memiliki kriteria tinggi. Berdasarkan perbandingan post-test I dan post-test II menunjukkan perubahan yang sangat besar. Pada posttest siklus II sudah tidak ditemukan siswa yang memiliki komunikasi rendah.

\section{4) Observasi}

Pada siklus II, observasi dilakukan selama kegiatan tindakan berlangsung yaitu pada tindakan I dan tindakan II. Hasil observasi tindakan I yaitu naposo nauli bulung yaitu secara keseluruhan diskusi yang dilakukan berjalan dengan baik akan tetapi masih terlihat kurangnya keaktifan dan keseriusan anggota kelompok dalam melakukan kegiatan bimbingan kelompok tersebut, ini dapat dilihat dari hanya dua tiga orang yang mau mengeluarkan pendapatnya saat proses bimbingan kelompok berlangsung.

Sedangkan pada tindakan II ini naposo nauli bulung sudah terlihat aktif dalam berdiskusi. Saat diskusi berlangsung semua anggota kelompok sudah mau menyampaikan pendapatnya tanpa ditunjuk oleh peneliti, mereka secara sukarela secara bergiliran memaparkan pendapatnya tanpa malu-malu.

5) Kesimpulan

Pelaksanaan siklus II berjalan dengan lancar. Naposo nauli bulung sudah mampu menjalin komunikasi dengan baik dan mengetahui bagaimana bergaul dengan teman. Manfaat dari kegiatan ini sangat dirasakan oleh naposo nauli bulung dengan meningkatnya komunikasi. Hal ini terlihat dari perbedaan skor poin post-test siklus I dengan post-test siklus II.

6) Refleksi II

Refleksi dilakukan dengan cara berdiskusi yaitu diskusi antara peneliti dengan naposo nauli bulung, peneliti dengan guru kolaborator, serta peneliti dengan observer. Diantaranya adalah: 
a) Tidak ada naposo nauli bulung yang masih hanya mau akrab dengan teman bermainnya. Semua naposo nauli bulung menjadi lebih dekat dan akrab.

b) Tindakan I semula berjalan agak kaku, tetapi bisa diatasi peneliti dengan penunjukkan dan selalu mengajak seluruh naposo nauli bulung untuk aktif dalam diskusi. Sedangkan pada tindakan II, naposo nauli bulung sudah terbiasa dengan anggota, sehingga diskusi dapat berjalan dengan lancar.

c) Hasil siklus II menunjukkan bahwa rata-rata skor poin angket komunikasi naposo nauli bulung 84,7. Jumlah siswa yang memiliki kriteria komunikasi rendah dibawah 56 adalah 0. Adapun kriteria keberhasilan yang diinginkan adalah naposo nauli bulung minimal berkriteria sedang (56 poin) sudah terpenuhi, maka dari itu penelitian dihentikan.

\section{PEMBAHASAN}

Berdasarkan pengamatan yang dilakukan pada anggota bimbingan kelompok naposo nauli bulung desa Sihepeng Induk cenderung melakukan kesalahpahaman dalam berkomunikasi, mereka sering bertentangan satu sama lain dalam memberikan saran dan pendapat dalam satu kegiatan. Sebelum dilakukannya tindakan, inilah masalah yang dihadapi naposo nauli bulung. Hal tersebut mengakibatkan naposo nauli bulung kurang nyaman bergaul dan menjalin komunikasi dengan naposo nauli bulung lainnya. Sehingga mereka bergaulnya dengan membentuk kelompok, baik untuk bermain, bekrjasama dalam mengerjakan tugas, dan untuk menjatuhkan kelompok lain. Sebenarnya ketua naposo nauli bulung sudah berusaha menyelesaikan

permasalahan tersebut dengan memberikan nasehat dan motivasi kepada anggotanya untuk saling bekerja sama, saling terbuka dan selalu kompak dalam hal apapun, namun kenyataannya pertentangan itu terus terjadi walaupun sebelumnya sudah mereka sepakati untuk menjalin kekompakan.

Sebagian besar naposo nauli bulung desa Sihepeng Induk kesulitan dalam berkomunikasi dengan berbagai alasan. Hal tersebut terlihat dalam hasil observasi dan hasil angket pra siklus yang menunjukkan bahwa dari 30 naposo nauli bulung terdapat 8 orang dengan hasil angket komunikasi rendah, masalah tersebut berusaha diperbaiki dengan layanan yang tepat. Penelitian ini menggunakan layanan bimbingan kelompok dengan teknik bermain peran.

Berdasarkan hasil penelitian dan uraian diatas dapat disimpulkan bahwa layanan bimbingan kelompok dengan teknik bermain peran dapat meningkatkan komunikasi naposo nauli bulung. Naposo nauli bulung yang komunikasinya baik memiliki berbagai macam kecakapan yaitu keterampilan berbicara, keterampilan bertanya, keterampilan membuka pintu 
komunikasi, keterampilan menjaga sopan santun, keterampilan meminta maaf pada saat merasa bersalah, cepat tanggap dan bertanggung jawab, perhatian dan kepedulian, memiliki empati, dan keterampilan mendengarkan (Suranto 2011:94).

Berdasarkan kegiatan pra penelitian di desa Sihepeng Induk ditemukan beberapa naposo nauli bulung dengan karakteristik komunikasi yang rendah. Gejala-gejala ini tampak pada kurangnya keterampilan dalam berbicara seperti kurang siap dalam berbicara dengan orang lain, ragu-ragu dalam mengucapkan kata-kata, kata yang keluar kurang tertata dengan baik, sulitnya memulai komunikasi dengan orang lain, sering memotong pembicaraan orang lain yang belum selesai bicara, kurang memiliki kepedulian terhadap apa yang dikerjakan oleh teman-temanya, kurang berempati terhadap permasalahan orang lain, ketika bertanya identik untuk menyinggung perasaan orang lain.

Budyatna \& Ganiem (2011:7) mengemukakan bahwa sedikit sekali di masyarakat kita komunikasi yang dapat dikarakteristikkan sebagai komunikasi yang baik. Setiap orang berbeda dalam kemampuannya dalam memiliki keterampilan komunikasi. Tidak semua orang melakukan komunikasi dengan baik, dari faktor inilah banyak terdapat permasalahan dalam berkomunikasi. Komunikasi merupakan kegiatan aktif bukan pasif. Komunikasi bukan hanya pengirim pada penerima pesan, begitupula sebaliknya, melainkan komunikasi timbal balik antara pengirim dan penerima pesan. Agus M. Hardjana (dalam Suranto, 2011:3) mengemukakan komunikasi adalah interaksi tatap muka antar dua atau beberapa orang, di mana pengirim dapat menyampaikan pesan secara langsung pula. Komunikasi bukan sekedar serangkaian rangsangan-tanggapan, stimulus-respon, akan tetapi serangkaian proses saling menerima, penyerahan dan penyampaian tanggapan yang telah diolah oleh masing-masing pihak. Hal tersebut sesuai dengan hasil penelitian (Rizky Andana Pohan: 2016) bahwa respon individu dipengaruhi oleh faktor dari dalam diri individu itu sendiri antara lain persepsi dan kepercayaan diri. Oleh sebab itu untuk meningkatkan respon dalam berkomunikasi perlu ditingkatkan kepercayaan diri dan dirubah persepinya menjadi semakin positif. Salah satu layanan yang dapat menigkatkannya adalah layanan bimbingan kelompok.

Dengan pelaksanaan layanan bimbingan kelompok dengan teknik bermain peran, setidaknya telah memberikan jawaban terhadap permasalahan yang terjadi terhadap naposo nauli bulung di Desa Sihepeng Induk. Melalui tindakan ini keterampilan komunikasi mengalami peningkatan, dari sebelumnya 8 orang yang memilki skor poin dengan criteria rendah menjadi 0 . Hal ini ditandai dengan berbagai macam karakteristik naposo nauli bulung yang sudah menunjukkan cara berkomunikasi dengan baik seperti kemampuan dalam berbicara, bertanya, membuka diri untuk berkomunikasi, saling menghargai, empati dan 
menjadi pendengar yang baik ketika orang lain sedang berbicara. Komunikasi adalah proses pertukaran informasi serta pemindahan pengertian antara dua orang atau lebih dari suatu kelompok manusia kecil dengan berbagai efek dan umpan balik.

Agar komunikasi yang dilakukan menghasilkan hubungan yang efektif dan kerjasama bisa ditingkatkan maka kita perlu bersikap terbuka, sikap percaya, sikap mendukung, dan terbuka yang mendorong timbulnya sikap yang saling memahami, menghargai, dan saling mengembangkan kualitas.

\section{KESIMPULAN}

Berdasarkan hasil penelitian dan pembahasan diperoleh kesimpulan bahwa dengan pelaksanaan layanan bimbingan kelompok melalui pendekatan teknik bermain peran dapat meningkatkan komunikasi pada naposo nauli bulung desa Sihepeng Induk.

a. Pelaksanaan layanan bimbingan kelompok melalui pendekatan teknik bermain peran

Pada awalnya naposo nauli bulung masih kurang aktif dalam kegiatan kelompok dan masih malu-malu mengungkapkan pendapatnya dimuka umum, oleh karena itu dalam kegiatan kelompok harus ditunjuk peneliti dengan nada memaksa untuk menyampaikan pendapatnya.

Selanjutnya naposo nauli bulung sudah cukup aktif dalam kegiatan kelompok dan berani dalam mengungkapkan pendapatnya di muka umum, walaupun tidak semua anggota kelompok, juga masih ada yang berdasarkan perintah dari peneliti baru berani. Tapi secara keseluruhan sudah terlihat peningkatannya.

b. Komunikasi naposo nauli bulung

Naposo nauli bulung terdiri dari kelompok tersendiri (geng), akibatnya komunikasi cenderung tertutup. Komunikasi hanya terjadi diantara kelompok (geng) mereka saja. Sekarang naposo nauli bulung lebih terbuka dan percaya diri untuk menjalin komunikasi dengan orang lain, kelompok(geng) naposo nauli bulung yang sebelumnya terbentuk sudah tidak ada lagi, semua naposo nauli bulung sudah menjadi satu kelompok(geng) yang saling bekerja sama dan saling terbuka dalam menjalin komunikasi.

\section{SARAN}

Berdasarkan kesimpulan diatas, saran yang dapat diberikan terkait penelitian ini adalah sebagai berikut:

a. Bagi ketua naposo nauli bulung

Dalam meningkatkan komunikasi hendaknya dirancang kegiatan mingguan berupa pengajian yang dilakukan di rumah anggota naposo nauli bulung secara bergiliran, 
diadakan minimal sekali dalam sebulan kegiatan berupa outbound dialam terbuka yang menarik dan memberi nilai positif, mengajak membuat kreatifitas yang sesuai dengan bakat naposo nauli bulung guna memperkuat jalinan komunikasi antar naposo nauli bulung.

b. Bagi anggota naposo nauli bulung

Harus menanamkan niat dari hati untuk lebih bekerja keras untuk menjalin kekompakan dan saling terbuka antar sesama napaso nauli bulung.

c. Bagi orang tua

Hendaknya memberi dukungan dan referensi dalam menjalin komunikasi yang baik dengan orang lain.

d. Bagi kepala desa

Ikut serta berperan aktif memberikan motivasi dalam kegiatan organisasi naposo nauli bulung.

e. Bagi peneliti selanjutnya

Pada penelitian ini, upaya peningkatan komunikasi hanya dilakukan melalui layanan bimbingan kelompok dengan teknik bermain peran. Untuk pengembangan penelitian selanjutnya dapat dilakukan dengan berbagai macam tindakan yang lebih kreatif dan inovatif. 


\section{DAFTAR RUJUKAN}

Effendi, Onong Uchyana. 1993. Ilmu Komunikasi: Teori dan Praktek. Bandung: Remaja Rosdakarya.

Giri, Isni Putra. 2013. Bimbingan Kelompok dengan Teknik Role playing. Jakarta: Prisma.

Hafied Cangara. 2004. Pengantar Ilmu Komunikasi. Jakarta: Raja Grafindo Persada.

Hamdani . 2011. Strategi Belajar Mengajar. Bandung: Pustaka Setia.

J.J. Hasibuan dan Moedjiono. (2006). Proses belajar mengajar. Bandung: Remaja Rosdakarya.

Lexy, J. Moleong, 2002 Metodologi Penelitian Kualitatif, cet.13 Bandung : Remaja Rosdakarya.

Mulyana, Deddy. 2007. Ilmu Komunikasi Suatu Pengantar. Bandung: Remadja Karya.

Mulyasa. (2009). Praktik Penelitian Tindakan Kelas. Bandung: Remaja Rosdakarya.

Nidya, Damayanti. 2012. Panduan Bimbingan dan Konselingi. Yogyakarta: Araska.

Paizaluddin \& Ermalinda,2014. Penelitian Tindakan Kelas. Bandung: Alfabeta.

Pohan, R. A. (2016). Kontribusi Kepercayaan Diri dan Persepsi Siswa Terhadap Kegiatan Merespon Dalam Pembelajaran Serta Implikasinya Dalam Bimbingan dan Konseling. Jurnal Penelitian Bimbingan dan Konseling, 1(2).

Rakhmat, Jalaluddin. 2001. Psikologi Komunikasi, Remaja. Bandung: Rosdakarya.

Riswandi. 2013. Psikologi Komunikasi. Yogyakarta: Graha Ilmu.

Roestiyah (2001). Strategi belajar mengajar. Jakarta: rineka cipta Asti Mahasatsa.

Supriatna, Mamat, 2011. Bimbingan dan Konseling Berbasis Kompetensi: Orientasi Dasar Pengembangan Profesi Konselor. Jakarta: PT Raja Grafindo Persada 